\title{
Fluvial discharge and sea-level changes controlling black shale deposition during the Paleocene-Eocene Thermal Maximum in the Dababiya Quarry section, Egypt
}

\author{
Peter Schulte ${ }^{\mathrm{a}, *}$, Christian Scheibner ${ }^{\mathrm{b}}$, Robert P. Speijer ${ }^{\mathrm{c}}$ \\ a GeoZentrum Nordbayern, Universität Erlangen, D-91054 Erlangen, Germany \\ ${ }^{b}$ Department of Geosciences, Bremen University, P.O. Box 330440, D-28334 Bremen, Germany \\ c Department of Earth and Environmental Sciences, K.U.Leuven, B-3001 Leuven, Belgium
}

\section{A R T I C L E I N F O}

\section{Article history:}

Received 22 April 2010

Received in revised form 1 December 2010

Accepted 5 April 2011

Available online 12 April 2011

Editor: J.D. Blum

\section{Keywords:}

Eocene

Continental shelf

Sequence stratigraphy

Hyperthermal

Carbon cycle

Ocean acidification

\begin{abstract}
A B S T R A C T
The formation of black shales along the Tethyan margins at the Paleocene-Eocene Thermal Maximum ("PETM"; $55 \mathrm{Ma}$ ) may have been an important feedback mechanism to reduce the warming by excess carbon burial. However, the detailed evolution of sediment redox conditions during this event is still poorly constrained. We address this issue by a high-resolution mineralogical and geochemical investigation of the outer neritic Dababiya Quarry PETM section in Central Egypt, which serves as the Global boundary Stratotype Section and Point for the base of the Eocene. There, the base of the PETM beds corresponds to the onset of sediment lamination indicative of oxygen-deficiency at the seafloor. The absence of calcium carbonate and a major increase in phyllosilicate abundance and change in detritus-sensitive trace elements is indicative of severe carbonate dissolution in addition to enhanced fluvial input, erosion of coastal low lands, and deposition during low or slightly rising sea level. Subsequently, fully anoxic conditions were established for a short period during the peak phase of the PETM as recorded by the strong relative enrichment of redox-sensitive trace elements and organic carbon compared to background sediments. The decoupling of the Fe and Mo contents from the detrital fraction may even indicate that euxinic conditions existed with free hydrogen sulfide in the water column. Concurrent to the onset of anoxia, high carbonate and quartz contents as well as high elemental ratios of $\mathrm{Si} / \mathrm{Al}$ suggest a major drop of siliciclastic sediment supply (sediment starvation), most likely caused by a rapid sea level rise. The final recovery phase of the PETM is associated with a progressive restoration of the pre-PETM siliciclastic sedimentation, temporary (seasonal) anoxic to dysoxic conditions, and high phosphorus enrichment, followed by carbonate-dominated sedimentation and the return to welloxygenated conditions.

We conclude that after a period of strong fluvial discharge, several parameters inherent to the PETM (e.g., warming, water-column stratification, and enhanced fluvial discharge) may have contributed to the development of anoxia and increased the burial efficiency of organic carbon by reducing water column oxygenation. The temporal coincidence of sediment starvation and onset of black shale deposition during the PETM suggests that a rapid sea-level rise was an additional important triggering factor. Therefore, our results support not only current views that Tethyan continental shelf areas may have acted as large carbon sinks during the PETM, but also indicate that transgressions may have provided an important feedback mechanism for organic carbon drawdown during hyperthermal events.
\end{abstract}

(c) 2011 Elsevier B.V. All rights reserved.

\section{Introduction}

The sudden and massive input of isotopically light carbon into the ocean-atmosphere system during the earliest Eocene $(\sim 55 \mathrm{Ma})$ had dramatic environmental consequences for the marine and terrestrial realms (e.g., Kennett and Stott, 1991; Dickens et al., 1995). Global temperatures increased by about 5 to $8^{\circ} \mathrm{C}$ (Bowen et al., 2006; Sluijs et al., 2007) and large parts of the deep oceans were "acidified" (Zachos et al.,

\footnotetext{
* Corresponding author.

E-mail address: schulte@geol.uni-erlangen.de (P. Schulte).
}

2005). The onset of this Paleocene-Eocene Thermal Maximum ("PETM"), which is marked by a prominent negative carbon isotope excursion ("CIE", Dickens et al., 1995), occurred rapidly within a few thousand years ("ky") although the mechanisms for the carbon release and its amount are still unclear (Bains et al., 1999; Higgins and Schrag, 2006; Pagani et al., 2006a; Bowen and Bowen, 2008). The subsequent progressive return to pre-PETM environmental conditions occurred in less than 200 ky (Röhl et al., 2007) and was possibly enhanced by $\mathrm{CO}_{2}$-triggered increased weathering and bioproductivity feedback effects. Thus, the environmental consequences of this event are very similar to the proposed consequences of the current large-scale $\mathrm{CO}_{2}$ release (e.g., global warming and ocean acidification; Trenberth et al., 2007). Consequently, the PETM 